\title{
PENGEMBANGAN PUZZLE BERBASIS AUGMENTED REALITY UNTUK PENANAMAN NILAI PANCASILA BAGI SISWA KELAS 4 SD IT
}

\author{
Nifta Noor Halimah ${ }^{1}$, Sungkono ${ }^{2}$ \\ Kurikulum Teknologi Pendidikan, Fakultas Ilmu Pendidikan, Universitas Negeri Yogyakarta \\ e-mail: niftanoor.2017@student.uny.ac.id, sungkono@uny.ac.id
}

\begin{abstract}
Abstrak
Penelitian ini bertujuan untuk: (1) Menghasilkan Alat Permainan Edukatif puzzle Puzila berbasis augmented reality sebagai penanaman nilai-nilai pancasila di kelas 4 SD IT Bina Insan Kamil, dan (2) Mengetahui kelayakan Alat Permainan Edukatif puzzle Puzila berbasis augmented reality berdasarkan validasi dari ahli materi dan ahli media. Penelitian ini merupakan penelitian pengembangan APE yang dikembangkan dengan menggunakan model 4-D dari Thiagarajan. Subjek penelitian ini adalah siswa kelas 4 SD IT Bina Insan Kamil, Turi, Sleman, Yogyakarta yang berjumlah 12 anak. Teknik analisis data dalam penelitian ini menggunakan teknik deskriptif kuantitatif untuk mengetahui kelayakan dari media. Berdasarkan hasil penelitian yang sudah dilakukan maka pengembangan APE Puzzle Puzila telah menempuh 4 langkah dari model 4-D dari Thiagarajan yaitu tahap Define (Pendefinisian), Design (Perancangan), Develop (Pengembangan), dan Disseminate (Penyebarluasan). Hasil penelitian membuktikan bahwa media Puzzle Puzila layak untuk digunakan untuk siswa kelas 4 SD IT Bina Insan Kamil dalam materi penanaman nilai-nilai pancasila. Hal tersebut terbukti dari hasil validasi ahli materi yang memperoleh skor rata-rata sebesar 4,1 (Layak), validasi ahli media dengan perolehan skor rata-rata sebesar 4,3 (Layak), validasi guru dengan perolehan skor rata-rata sebesar 4,2 (Layak) dan tahap uji coba siswa diperoleh skor rata-rata dari data respon sebesar 1 (Layak).
\end{abstract}

Kata Kunci: Game Puzzle, Augmented Reality, Penanaman Nilai Pancasila

\section{PUZZLE BASED ON AUGMENTED REALITY FOR PLANTING PANCASILA VALUES IN CLASS 4 PRIMARY SCHOOL OF IT}

\begin{abstract}
This study aims to: (1) Produce an Pancasila Puzzle Educational Game Tool (PUZILA) based on Augmented Reality for planting of Pancasila values in Grade 4 at SD IT Bina Insan Kamil, and (2) Determine the feasibility of an Pancasila Puzzle Educational Game Tool (PUZILA) based on Augmented Reality based on validation from material experts and media experts. This research is an Educational Game Tool development research which was developed using a 4-D model from Thiagarajan. The subjects of this study were Grade 4 students of SD IT Bina Insan Kamil, Turi, Sleman, Yogyakarta, totaling 12 children. The data analysis technique in this study used quantitative descriptive techniques to determine the feasibility of the media. Based on the results of the research that has been done, the Puzila Puzzle media development has gone through 4 steps from the 4-D model from Thiagarajan, namely the Define, Design, Develop, and Disseminate stages. The results of the study prove that the Puzila Puzzle media is suitable for use for grade 4 students of SD IT Bina Insan Kamil in the material for planting Pancasila values. This is evident from the results of material expert validation who obtained an average score of 4.1 (Feasible), media expert validation with an average score of 4.3 (Feasible), teacher validation with an average score of 4,2 (Feasible) and the student trial stage obtained an average score from the response data of 1 (Feasible).
\end{abstract}

Keywords: Puzzle Games, Augmented Reality, Planting Pancasila Values

\section{PENDAHULUAN}

Pendidikan merupakan salah satu upaya Indonesia dalam menumbuhkan kecerdasan bangsa sebagai cita-cita nasional yang harus diwujudkan. Manusia yang cerdas dibutuhkan dalam memajukan suatu negara, baik dalam segi pembangunan negara, ekonomi maupun sosial dan budaya. Pendidikan sangatlah penting untuk dapat menciptakan manusia dengan segala kualitasnya. Melalui 
pendidikan, perkembangan ilmu pengetahuan dan teknologi akan lebih mudah dicerna oleh manusia sehingga memungkinkan suatu negara atau bangsa tersebut lebih maju. Sementara itu, perkembangan ilmu pengetahuan dan pemanfaatan teknologi dalam dunia pendidikan semakin maju dan berkembang mengikuti perkembangan zaman. Hal tersebut menuntut adanya pembaharuan untuk dapat mengimbanginya. Pada dasarnya penggunaan tools tersebut tidak digunakan khusus untuk keperluan pendidikan, namun dapat dimanfaatkan dalam dunia pendidikan untuk pembelajaran (Budiman, 2017: 32).

Pada era globalisasi dengan segala kemajuan kehidupannya saat ini, Indonesia harus mampu untuk bersaing dengan negara lain. Namun dengan motivasi tersebut, kita tidak boleh kehilangan jati diri dan karakter bangsa. Oleh karena itu, kita harus menanamkan jati diri bangsa kepada generasi penerus sedari dini melalui salah satu upaya nya yaitu bidang pendidikan. Upaya tersebut juga diharapkan terwujud melalui pendidikan Indonesia dengan pembelajaran Kewarganegaraan. Pendidikan Kewarganegaraan pada dasarnya menjadi ujung tombak pembentukan karakter anak bangsa melalui pemahaman ideologi bangsa yaitu Pancasila. Pancasila mengajarkan nilainilai kepribadian luhur bangsa dan sangat penting untuk menumbuhkan pola pikir, sikap serta perilaku berbangsa. Selama ini kendala utama pendidikan Kewarganegaraan di dalam proses pembelajaran di kelas adalah selalu menekankan pada aspek kognitif sehingga aspek afektif atau karakter peserta didik kurang diperhatikan sebagai tujuan pembelajaran. Selain itu, metode pembelajaran yang monoton juga menjadi penyebab tidak maksimalnya proses pembangunan karakter peserta didik (Widiatmaka, 2016: 197). Padahal penting sekali bagi mereka generasi muda untuk dapat mengetahui dan memahami tentang bangsa dan negara Indonesia. Oleh karena itu, pendidikan Kewarganegaraan merupakan mata pelajaran yang wajib dan harus dipelajari oleh anak-anak mulai dari sekolah dasar. Hal ini dilakukan sebagai upaya membentuk pribadi anak sebagai generasi penerus bangsa yang baik. Kedepannya anakanak juga akan terjun ke masyarakat, sehingga mereka harus paham dan mampu mengaplikasikan nilai-nilai Pancasila dengan baik. Anak-anak sebagai generasi penerus bangsa harus dapat menjaga Pancasila dan UUD 1945 sebagai dasar negara bangsa Indonesia.

Mata pelajaran Kewarganegaraan atau yang sering disebut dengan PKn adalah mata pelajaran yang harus diberikan dengan baik agar anak-anak tahu dan paham. Namun, pada kenyataannya justru terbalik, anak-anak zaman sekarang justru tidak sedikit yang belum hafal dengan Pancasila. Menurut survei yang dilakukan oleh Unit Kerja Presiden Pembinaan Ideologi Pancasila (UKP PIP) pada tahun 2018 terdapat 24 orang dari 100 orang Indonesia yang tidak hafal dengan setiap sila pada Pancasila. Masalah terbesarnya adalah bagaimana dapat mengimplementasikan nilainilai Pancasila dalam kehidupan sehari-hari, jika tahu dan paham saja tidak. Penting untuk diperhatikan secara mendalam dan harus segera ditemukan solusi untuk permasalahan bangsa tersebut. Hal ini seharusnya tidak terjadi, jika pendidikan Kewarganegaraan dapat disampaikan dengan baik dan dimengerti oleh anak sejak dini. Namun dalam praktiknya, siswa sering kali merasa berat dalam belajar karena terlalu banyak materi atau hafalan yang harus dipelajari dalam pendidikan Kewarganegaraan. Padahal yang harus lebih ditekankan adalah bentuk afektif atau perilaku siswa dibandingkan kognitifnya.

Berdasarkan wawancara yang dilakukan penulis kepada wali kelas 4 SD IT Bina Insan Kamil pada tanggal 14 Februari 2021 pukul 08.00 , menyatakan bahwa siswa merasa kesulitan dalam pembelajaran Kewarganegaraan karena materi yang terlalu banyak serta tuntutan dari kurikulum. Sementara itu, SD IT merupakan sekolah dasar yang menekankan pada terciptanya siswa dengan kepribadian yang luhur dengan lebih mengajarkan pada bentuk afektif dibandingkan kognitif. Dalam pembelajaran di kelas, guru menggunakan media pembelajaran berupa buku dan papan tulis sebagai media mengajar di kelas. Disamping itu, metode pembelajaran yang digunakan di kelas adalah metode diskusi dan problem solving sesuai tuntutan kurikulum 2013. Dalam wawancara tersebut, guru juga menyatakan bahwa ketersediaan media pembelajaran pendukung di kelas dalam pembelajaran Kewarganegaraan sangatlah minim sehingga siswa mudah merasa bosan saat belajar di kelas. Berdasarkan wawancara dan dokumen raport yang diperoleh dari wali kelas 4 juga menunjukkan bahwa rata-rata 
nilai dalam mata pelajaran PKn sebesar 76,8 dan merupakan rata-rata nilai paling rendah dibandingkan mata pelajaran lain. Hal tersebut sebanding dengan ungkapan wali kelas bahwa siswa kesulitan untuk belajar materi dalam pembelajaran Kewarganegaraan.

Sejalan dengan hal tersebut, peneliti juga melakukan wawancara kepada siswa Kelas 4 SD IT Bina Insan Kamil pada tanggal 15 Februari 2021 yang memberikan kesimpulan bahwa siswa lebih suka belajar dengan menggunakan Alat Permainan Edukatif dan video pembelajaran, namun karena keterbatasan media yang ada siswa menjadi bosan dan tidak memahami materi karena tidak semangat dalam belajar. Pengembangan media pembelajaran ni dilakukan untuk menciptakan media pembelajaran yang inovatif, menarik dan tidak ketinggalan zaman. Media yang menarik akan mampu meningkatkan motivasi dan pemahaman siswa dalam menyerap materi pembelajaran, terutama untuk mata pelajaran Kewarganegaraan. Namun, pada praktiknya dalam pembelajaran di kelas, tidak semua guru mampu mengembangkan media pembelajaran yang menarik sesuai dengan karakteristik dan kebutuhan siswa. Kemampuan dan keterampilan guru yang minim menyulitkan mereka untuk dapat berinovasi lebih. Guru yang menguasai materi pembelajaran, belum tentu mampu menghadirkan bentuk media pembelajaran menarik yang menggunakan teknologi di kelas.

Hasil observasi dan wawancara kepada kepala sekolah yang dilakukan oleh penulis pada tanggal 28 September 2020 di SD IT Bina Insan Kamil, Lungguhrejo, Wonokerto, Turi, Sleman, Yogyakarta, sejalan dengan apa yang sudah diuraikan di atas. Berdasarkan hasil observasi dan wawancara tersebut, ditemukan hambatan dalam pelaksanaan proses pembelajaran, yaitu kurangnya pemanfaatan media pembelajaran pendukung di kelas. Masih minimnya guru yang memanfaatkan media permainan edukatif atau media berteknologi sebagai media dan sarana pembelajaran terutama pada mata pelajaran pendidikan Kewarganegaraan, menyebabkan siswa kesulitan untuk memahami materi. Siswa sendiri lebih suka dengan pembelajaran yang bervariatif dan menarik perhatian. Sementara itu, media dalam pembelajaran pendidikan Kewarganegaraan masih terbatas ketersediaannya terutama untuk media Alat
Permainan Edukatif, video pembelajaran dan aplikasi pembelajaran. Media pembelajaran yang mencukupi lebih ada pada mata pelajaran IPA dan Matematika. Oleh karena itu, perlu adanya inovasi yang tepat dalam membantu para guru dan siswa di SD IT Bina Insan Kamil agar pembelajaran Kewarganegaraan dapat berjalan dengan efektif serta siswa dapat memahami Pancasila serta nilai-nilai yang terkandung di dalamnya.

Alat Permainan Edukatif atau disingkat dengan APE adalah segala bentuk media permainan yang mampu memberikan pengetahuan kepada anak dan meningkatkan kemampuannya(Suyadi, 2009 : 53). Dalam Suyadi (2009 : 83), dijelaskan bagaimana cara memilih sebuah jenis permainan edukatif yang dapat bebas dari dampak negatif, yaitu a) Disesuaikan dengan perkembangan anak, b) Aman, c) Menyenangkan, d) Mencerdaskan aspek tertentu. Alat Permainan Edukatif yang digunakan adalah alat bermain yang bertujuan untuk belajar dan pembelajaran. Indikator alat permainan tersebut memberikan pembelajaran atau edukatif adalah jika mampu mengembangkan aspek tertentu di diri anak atau peserta didik. Sependapat dengan Suyadi, Soetjiningsih (2002) dalam Ariyanti dan Zidni (2015 : 62) mengemukakan bahwa Alat Permainan Edukatif merupakan alat permainan yang dapat mengoptimalkan perkembangan anak sesuai dengan usia dan tingkat perkembangan anak. Hal ini berguna untuk pengembangan aspek fisik, bahasa, kognitif dan sosial anak. Menurut Yudha (2007 : 33), puzzle games merupakan suatu gambar yang dibagi menjadi potongan-potongan gambar terpisah yang bertujuan untuk melatih kesabaran anak. mengasah daya pikir anak serta dapat membiasakan anak untuk senang berbagi. Puzzle termasuk dalam jenis Alat Permainan Edukatif karena digunakan tidak hanya untuk bermain, melainkan juga mengasah otak dan melatih keseimbangan antara pikiran dan motorik tangan. Permainan puzzle dapat dimainkan di rumah maupun untuk belajar di sekolah. Puzzle dapat menarik perhatian anak untuk dapat bermain sambil belajar. Puzzle merupakan media yang paling umum digunakan dan termasuk media pembelajaran sederhana yang dapat digunakan dalam dunia pendidikan karena puzzle biasanya disukai oleh siswa, harganya terjangkau, serta mudah didapatkan (Hamalik, 1980 dalam Yusliawan, 2014: 330). 
Keunggulan dari media ini sendiri adalah untuk meningkatkan kemampuan berpikir siswa, siswa dapat belajar untuk berkonsentrasi, melatih sel-sel otak siswa, mengembangkan pikiran siswa, melatih siswa untuk fokus berkonsentrasi dan meningkatkan keterampilan kognitif siswa (Susilana dan Riyana, $2007: 3$ ).

Menurut Buchori (2017:138) media pembelajaran android berformat apk yang dapat dipilih sesuai dengan karakteristik geometri adalah aplikasi android yang menggunakan teknologi Augmented Reality. (Azuma, 1997:355) Augmented Reality adalah sebuah teknologi yang dapat menggabungkan benda virtual berbentuk 2 dimensi atau 3 dimensi menjadi sebuah bentuk 3 dimensi nyata di lingkungan kita dan memproyeksikan benda-benda virtual tersebut secara real time dengan bantuan ponsel android dalam penggunaannya. Saputro \& Saputra (2014 : 154) menjelaskan bahwa sebuah teknologi Augmented Reality atau dapat disebut juga sebagai Realitas Tertambah merupakan kelengkapan elemen digital yang ditambahkan secara langsung dan mengikuti keadaan lingkungan di dunia nyata serta dapat diterapkan pada perangkat mobile. Suharso (2011) menjelaskan bahwa penggunaan aplikasi pembelajaran menggunakan teknologi AR dapat mempermudah tugas seorang guru dalam menyajikan sebuah materi di kelas, mempersingkat durasi waktu untuk mengajar serta dapat menciptakan suasana belajar yang lebih interaktif. Kelebihan dari aplikasi yang menggunakan teknologi AR ini adalah memiliki interaktivitas yang tinggi, yakni dengan adanya obyek virtual AR yang dapat berinteraksi langsung dengan pengguna.

Mata pelajaran Pendidikan

Kewarganegaraan (PPKn) dinilai belum dapat memberikan dampak yang cukup besar dalam pembentukan karakter siswa. Hal ini disebabkan karena belum adanya implementasi penanaman nilai-nilai Pancasila secara konkret dan serius di sekolah, melainkan hanya sebatas pengetahuan. Strategi penanaman nilai Pancasila seharusnya diarahkan untuk lebih banyak memberikan contoh implementasinya dalam kehidupan sehari-hari. Mendikbud mengungkapkan bahwa guru harus dapat lebih memanfaatkan teknologi atau alat komunikasi untuk dapat mempermudah memberikan materi tersebut. Guru selain dituntut untuk dapat memanfaatkan teknologi informasi sebagai media pembelajaran juga harus terampil untuk dapat memilah konten mana yang menarik dan cocok untuk diajarkan pada peserta didiknya.

Penanaman nilai-nilai Pancasila harus ditanamkan sejak sekolah dasar. Namun faktanya, masih banyak siswa sekolah dasar yang belum paham mengenai bentuk-bentuk tindakan yang mencerminkan nilai-nilai pancasila. Seperti halnya yang terdapat di SD IT Bina Insan Kamil, Turi, Sleman, Guru mengungkapkan bahwa siswa masih kesulitan untuk menemukan contoh konkrit dari pengamalan nilai-nilai pancasila selain yang hanya tertera di buku. Hal itu berarti siswa belum paham betul mengenai nilai-nilai pancasila dan hanya menduplikat hal yang ada dibuku saja tanpa bisa mengimplementasikannya dalam kehidupan sehari-hari. Perlu kita perhatikan bersama bahwa penanaman nilai-nilai pancasila kepada anak sedari dini harus dilakukan dengan adanya kerjasama dari berbagai pihak, baik pemerintah, keluarga, maupun sekolah. Sekolah yang menjadi tempat anak menuntut ilmu harus lebih diperkuat lagi posisinya untuk dapat memahamkan siswa mengenai pancasila yang sesungguhnya. Memperkuat posisi bisa dilakukan dengan cara meningkatkan mutu dan kemampuan guru mengenai pendidikan kewarganegaraan, penyesuaian kurikulum yang lebih bersahabat akan penanaman nilai-nilai pancasila, serta memperbanyak bahan ajar dan media pembelajaran yang digunakan di sekolah.

Ada beberapa karakteristik anak di usia Sekolah Dasar yang perlu diperhatikan, agar guru lebih mengetahui keadaan peserta didik khususnya di tingkat Sekolah Dasar. Dengan mengetahui karakteristik siswa, maka guru dapat menerapkan metode pengajaran yang sesuai dengan keadaan siswanya. Oleh karena itu, hal tersebut sangatlah penting bagi seorang pendidik mengetahui karakteristik siswanya. Menurut Abdul Alim (2009) dalam Burhaein (2017 : 52), karakteristik anak usia Sekolah Dasar adalah (a) Senang bermain, (b) Senang bergerak, (c) Senang bekerja dalam kelompok, serta (d) Senang merasakan/ melakukan sesuatu secara langsung.

Berdasarkan beberapa kajian mengenai APE dan Augmented Reality dari beberapa ahli di atas, maka dapat disimpulkan bahwa media APE yang berupa Puzzle sangat cocok 
dikombinasikan untuk dijadikan media pembelajaran yang utuh. Selain untuk melatih daya pikir siswa dengan puzzle, pengenalan teknologi Augmented Reality juga diperlukan untuk memberikan pengetahuan baru kepada siswa dan guru bahwa terdapat model terbaru dalam perkembangan media pembelajaran saat ini. Penelitian dilakukan dalam rangka mengembangan media pembelajaran berbentuk Alat Permainan Edukatif berupa puzzle games dengan memanfaatkan teknologi Augmented reality yang diintegrasikan dalam sistem Android. Berdasarkan analisis kebutuhan sekolah membutuhkan APE dan siswa lebih menyukai belajar menggunakan video pembelajaran. Teknologi Augmented reality dapat menjembatani untuk mengkolaborasikan media APE dengan video pembelajaran. Media pembelajaran ini bertujuan untuk meningkatkan pemahaman siswa mengenai pemahaman nilai-nilai Pancasila sehingga mereka dapat mengimplementasikannya dalam kehidupan sehari-hari sejalan dengan visi dari SD IT Bina Insan Kamil sendiri. Alat Permainan Edukatif akan membuat pembelajaran lebih menarik dan tidak membosankan karena dilakukan dengan bermain. APE yang tepat untuk karakteristik siswa kelas 4 SD adalah puzzle karena dapat melatih daya pikir dan motorik siswa. Hal tersebut seuai dengan teori yang dikemukakan oleh Piaget bahwa anak yang berumur 7-11 tahun berada pada tahap operasional konkrit dimana penggunaan logika sangat memadai. Pengintegrasian teknologi Augmented reality ini juga akan membuat sekolah terutama siswa dan guru agar lebih melek teknologi dan mampu mengimplementasikan media berbasis teknologi dalam pembelajaran. Hal tersebut sangatlah penting, karena mengingat saat ini sudah berada pada era revolusi industri 4.0 yang memungkinkan untuk menggunakan teknologi dalam setiap lini kehidupan.

Berdasarkan latar belakang masalah yang sudah diuraikan di atas, maka penulis melakukan penelitian yaitu pengembangan Alat Permainan Edukatif puzzle Puzila berbasis augmented reality. Media ini merupakan media pembelajaran berbentuk puzzle bergambarkan lambang bangsa Indonesia yaitu Pancasila. Siswa kemudian menyusun kepingan-kepingan puzzle yang belum utuh menjadi bentuk utuh Pancasila. Selanjutnya siswa dapat menggunakan aplikasi
Augmented reality yang sudah terintegrasi dengan puzzle dengan melakukan scanning pada salah satu gambar lambang sila Pancasila. Setelah itu, pada aplikasi akan muncul video animasi yang menunjukkan perilaku yang dapat dicontoh dari penerapan salah satu sila Pancasila tersebut. Dengan media ini, diharapkan siswa dapat mengadopsi dan menerapkan perilaku baik yang dicontohkan dalam video dengan kehidupan sehari-harinya.

\section{METODE}

\section{Model Pengembangan}

Jenis pengembangan dalam penelitian ini menggunakan Research and Development (R\&D). Menurut Sugiyono (2016 : 297), metode R\&D adalah penelitian yang digunakan untuk menghasilkan sebuah produk dan menguji keefektifan dari produk tersebut apabila digunakan. Penelitian pengembangan mengacu pada model pada model 4D (Define, Design, Develop, dan Disseminate), yang diadaptasi dari Thiagarajan, (1974 : 5). Endang Mulyatiningsih (2011 : 200), menggambarkan tahapan desain pengembangan sebagai berikut:

1. Pendefinisian (Define)

2. Perancangan (Design)

3. Pengembangan (Develop)

4. Penyebarluasan (Disseminate)

\section{Prosedur Pengembangan}

Prosedur pengembangan meliputi tahap Define (Pendefinisian) terdiri atas tahap analisis awal, analisis siswa, analisis tugas, analisis konsep dan spesifikasi tujuan pembelajaran. Tahap Design (Perancangan) terdiri atas penyusunan instrumen penilaian kelayakan, pemilihan media, pemilihan format, dan rancangan awal media. Tahap Develop (Pengembangan) dilalui dengan tahap validasi ahli materi, ahli media, guru dan uji coba kepada siswa. Tahap Disseminate (Penyebarluasan) dilalui dengan tahap pengemasan dan pemberian identitas pengembang serta penyebarluasan dengan memberikan media kepada SD IT Bina Insan Kamil.

\section{Waktu dan Tempat Penelitian}

Waktu penelitian antara bulan Januari sampai Juni 2021 yang bertempat di Sleman Yogyakarta dengan lokasi di SD IT Bina Insan Kamil Turi Sleman. 


\section{Subjek Penelitian}

Subjek penelitian saat uji coba terbatas adalah sebanyak 12 siswa kelas 4 dalam 1 rombongan belajar di SD IT Bina Insan Kamil.

\section{Instrumen dan Teknik Pengumpulan Data}

Teknik pengumpulan data dari penelitian ini adalah angket/skala penilaian, wawancara dan observasi.

1. Panduan Wawancara

Panduan wawancara digunakan untuk mengetahui kebutuhan media, permasalahan pembelajaran dan seberapa pengaruhnya penggunaan media di sekolah. Wawancara dilakukan kepada guru wali kelas 4 dan siswa kelas 4 SD IT Bina Insan Kamil.

2. Panduan Observasi

Panduan observasi digunakan untuk mengetahui penggunaan media dalam pembelajaran di kelas melalui pengamatan yang dilakukan oleh peneliti. Observasi pada penelitian ini dilakukan untuk mengetahui penggunaan media dan fasilitas yang ada di kelas 4 SD IT Bina Insan Kamil, Turi, Sleman. Dengan adanya informasi tersebut, maka peneliti dapat menyesuaikan media yang akan dikembangkan dengan mempertimbangkan data hasil wawancara.

3. Skala Penilaian untuk Ahli Materi

Skala penilaian ini digunakan untuk mengetahui validitas dari materi Pancasila pada alat permainan edukatif puzzle puzzile berbasis Augmented reality yang dilakukan oleh ahli materi.

4. Skala Penilaian untuk Ahli Media

Skala Penilaian ini digunakan untuk mengetahui validitas dari produk alat permainan edukatif puzzle puzila berbasis Augmented reality yang dilakukan oleh ahli materi. Berikut merupakan kisi-kisi dari skala penilaian untuk ahli media.

5. Angket Respon untuk Guru

Angket respon ini digunakan untuk mengetahui kemudahan dalam penggunaan produk alat permainan edukatif puzzle puzila berbasis Augmented reality yang dilakukan oleh guru sebagai praktisi pembelajaran.

6. Angket Respon untuk Siswa

Angket Respon ini digunakan untuk mengetahui kemudahan dalam penggunaan produk alat permainan edukatif puzzle puzila berbasis Augmented reality yang dilakukan oleh siswa sebagai pengguna media.

\section{Teknik Analisis Data}

Teknik analisis data dalam penelitian ini menggunakan teknik deskriptif kuantitatif untuk mengetahui kelayakan dari media yang dikembangkan peneliti. Data yang diperoleh melalui kegiatan uji coba diklasifikasikan menjadi dua, yaitu data kualitatif dan data kuantitatif. Data kualitatif berupa saran yang dikemukakan ahli materi, ahli media, guru, dan peserta didik disimpulkan untuk dilakukan perbaikan produk media pembelajaran Puzila ini. Data kuantitatif (rata-rata nilai) yang diperoleh dari kuesioner selanjutnya dikonversikan ke data kualitatif dengan skala 5 (skala likert) untuk mengetahui kelayakan dari produk. Konversi skala 5 tersebut menggunakan acuan konversi pada Pendekatan Acuan Patokan (PAP) yang dikembangkan oleh Eko Putro Widoyoko (2009: 238).

Tabel 1. Konversi Skala Likert pada Tingkat Kelayakan

\begin{tabular}{ccc}
\hline Rentang & Kriteria & Kelayakan \\
\hline $\mathbf{X}>\mathbf{4 , 2}$ & Sangat Baik & \\
$\mathbf{3 , 4}<\mathrm{X}$ & Baik & Layak \\
$\leq \mathbf{4 , 2}$ & & \\
$\mathbf{2 , 6}<\mathrm{X}$ & Cukup & \\
$\mathbf{3} \mathbf{3 , 4}$ & & \\
$\mathbf{1 , 8}<\mathrm{X} \leq$ & Kurang & Tidak Layak \\
$\mathbf{2 , 6}$ & Sangat & \\
$\mathbf{X} \leq \mathbf{1 , 8}$ & Kurang & \\
\hline
\end{tabular}

Dalam penelitian ini, ditetapkan nilai kelayakan sebuah produk adalah dengan nilai minimal sebesar "3,4" dengan kategori "Baik". Sehingga hasil penilaian dari ahli materi dan ahli media jika telah didapat hasil penilaian akhir dengan nilai minimal, maka produk hasil pengembangan tersebut dianggap layak digunakan. Setelah dinilai layak maka dapat dilanjutkan ke tahap selanjutnya yaitu tahap uji coba. Selanjutnya teknis analisis data yang digunakan untuk uji coba lapangan (instrumen untuk siswa) adalah menggunakan skala Guttman. Skala ini menggunakan 2 jawaban yaitu "Ya" 
dan "Tidak". Jawaban "Ya" bernilai skor 1 dan jawaban "Tidak" bernilai skor 0 . Selanjutnya berdasarkan nilai kelayakan tersebut, maka dapat dihitung rata-rata skor angket respon siswa kemudian diubah ke dalam bentuk kualitatif berdasar tabel berikut.

Tabel 2. Konversi Skala Guttman pada Tingkat Kelayakan

\begin{tabular}{cc}
\hline Presentase Penilaian & Kriteria \\
\hline $\mathbf{0 , 5}<\mathbf{X} \leq \mathbf{1}$ & Baik \\
$\mathbf{0} \leq \mathbf{X} \leq \mathbf{0 , 5}$ & Tidak Baik \\
\hline
\end{tabular}

Jika hasil analisis data menunjukkan respon kriteria "Baik", maka alat permainan edukatif puzzle puzila yang dikembangkan oleh peneliti dianggap layak untuk digunakan dalam pembelajaran.

\section{HASIL DAN PEMBAHASAN}

Hasil dari penelitian ini adalah terciptanya produk berupa Alat Permainan Edukatif Puzzle Pancasila (Puzila) berbasis Augmented Reality yang dikembangkan dan diketahui kelayakannya untuk digunakan di subjek penelitian yaitu SD IT Bina Insan Kamil. Pengembangan produk ini dilakukan mengacu pada model 4D (Define, Design, Develop, dan Disseminate) yang diadaptasi dari Thiagarajan.

Tahap define (pendefinisian) terdiri atas analisis kurikulum, analisis karakteristik peserta didik, analisis materi, dan merumuskan tujuan. Dalam tahap ini dapat disimpulkan bahwa peneliti menemukan permasalahan di kelas 4 SD IT Bina Insan Kamil yaitu kurangnya media berupa Alat Permainan Edukatif serta mata pelajaran yang kurang medianya adalah pendidikan kewarganegaraan padahal sangat dibutuhkan oleh siswa untuk membantu dalam belajar.

Tahap design (perancangan) terdiri atas penyusunan instrumen, pemilihan media, pemilihan format dan rancangan awal. Penyusunan instrumen berupa instrumen penilaian dan angket. Pada tahap pemilihan media peneliti memutuskan untuk mengembangkan media berupa Alat Permainan Edukatif berdasarkan analisis yang sudah dilakukan di tahap sebelumnya. Sedangkan format yang dipilih oleh peneliti dalam penelitian ini adalah format APE berbentuk puzzle dengan berbantuan aplikasi android. Desain dari media dikembangkan dengan menggunakan perangkat komputer/laptop dan software Corel Draw $\mathrm{X} 21$. Pengembangan media puzzle dengan menggunakan kayu mdf sedangkan aplikasi Augmented Reality dikembangkan dengan menggunakan software Unity 3D. Hasil dari rancangan awal dari media Puzzle Puzila berbasis Pancasila yaitu berupa desain puzzle, petunjuk penggunaan, UI Aplikasi dan desain kemasan.

Tahap develop (pengembangan) dilakukan dengan melakukan penilaian dari media Puzzle Puzila yang sudah jadi kepada ahli materi, ahli media, guru dan uji coba kepada siswa. Hasil dari tahap ini adalah produk akhir APE Puzzle Puzila berbasis AR yang layak digunakan dalam pembelajaran PKn. Pada tahap ini dilakukan uji kelayakan produk berupa uji validasi materi, validasi media dan validasi praktisi pembelajaran. Hal tersebut untuk mengukur kelayakan media sebelum diuji coba kan kepada siswa kelas 4 SD IT Bina Insan Kamil. Pelaksanaan validasi sekaligus revisi dilakukan selama 1 bulan yaitu pada bulan Mei 2021. Kritik dan saran dari ahli dijadikan patokan untuk perbaikan media. Berikut merupakan hasil dari validasi oleh ahli materi, media dan guru sebagai praktisi pembelajaran.

\section{1) Validasi Ahli Materi}

Validasi oleh ahli materi bertujuan untuk mengetahui kelayakan dari materi dalam media puzzle puzila. Dalam tahap validasi materi, penilaian dilakukan oleh Fathurrohman, M.Pd selaku Dosen Program Studi Pendidikan Guru Sekolah Dasar FIP UNY yang secara khusus memiliki bidang keahlian pada pembelajaran pendidikan kewarganegaraan.

Tabel 3. Hasil Validasi Ahli Materi

\begin{tabular}{llcccc}
\hline No & \multicolumn{1}{c}{ Aspek } & $\begin{array}{c}\Sigma \\
\text { Skor }\end{array}$ & $\begin{array}{c}\Sigma \\
\text { Butir }\end{array}$ & $\overline{\mathbf{X}}$ & Kategori \\
\hline $\mathbf{1}$ & $\begin{array}{l}\text { Kesesuaian } \\
\text { materi dengan } \\
\text { tujuan } \\
\text { pembelajaran }\end{array}$ & 7 & 2 & 3,5 & Baik \\
$\mathbf{2}$ & $\begin{array}{l}\text { Dukungan } \\
\text { terhadap } \\
\text { materi }\end{array}$ & 8 & 2 & 4 & Baik \\
$\mathbf{3}$ & $\begin{array}{l}\text { Kemampuan } \\
\text { media dalam } \\
\text { menciptakan } \\
\text { suasana } \\
\text { pembelajaran }\end{array}$ & 8 & 2 & 4 & Baik
\end{tabular}




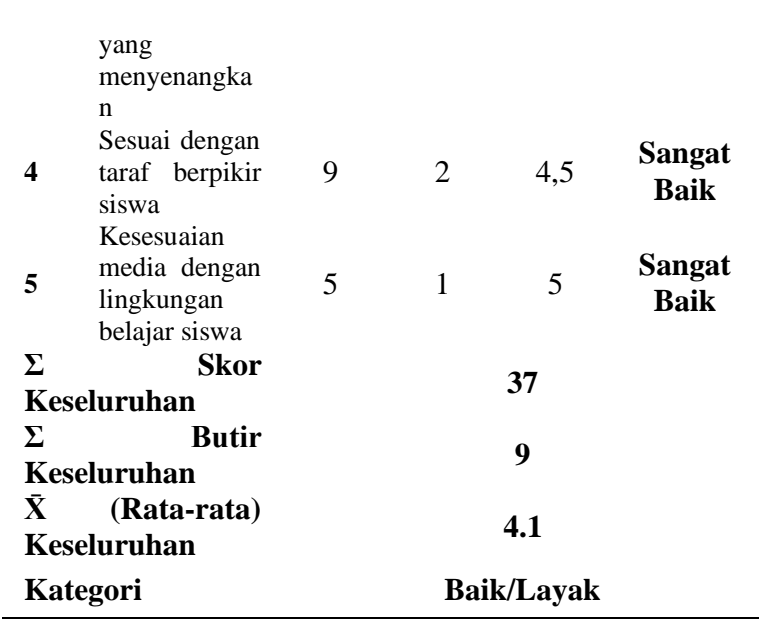

Berdasarkan hasil dari validasi materi tersebut, maka dapat disimpulkan bahwa media puzzle puzila memiliki skor total 37 dengan rata-rata 4,1 yang artinya media ini memiliki tingkat kelayakan dalam kategori "Baik". Ahli materi memberikan komentar bahwa Indikator 3.1.1 yang berbunyi "Menjelaskan makna sila pertama Pancasila" belum nampak pada soal di quiz aplikasi. Oleh karena itu peneliti harus memperbaiki bagian soal agar sesuai dengan indikator capaian. Setelah media berhasil diperbaiki berdasarkan saran dari ahli materi, maka peneliti mengkonsultasikan ke ahli materi tanpa harus mengisi ulang instrumen penilaian dan memperoleh kesimpulan "Layak untuk diuji cobakan tanpa revisi”.

\section{2) Validasi Ahli Media}

Validasi media oleh ahli media dilakukan bertujuan untuk mengukur kelayakan dari media puzzle puzila. Penilaian dilakukan oleh Ariyawan Agung Nugroho, S.T., M.Pd selaku Dosen Program Studi Teknologi Pendidikan FIP UNY. Penilaian dilakukan sebanyak 2 kali sebelum dilakukan uji coba kepada siswa SD IT Bina Insan Kamil sebagai subjek. Tahap pertama dilakukan pada tanggal 10 Mei 2021 pukul 11.00 bertempat di Kantor Jurusan Kurikulum dan Teknologi Pendidikan FIP UNY. Berikut merupakan hasil dari validasi pertama yang telah dilakukan:

Tabel 4. Hasil Validasi Ahli Media Tahap I

\begin{tabular}{llcccc}
\hline No & \multicolumn{1}{c}{ Aspek } & $\begin{array}{c}\Sigma \\
\text { Skor }\end{array}$ & $\begin{array}{c}\boldsymbol{\Sigma} \\
\text { Butir }\end{array}$ & $\overline{\mathbf{X}}$ & Kategori \\
\hline $\mathbf{1}$ & $\begin{array}{l}\text { Kesesuaian } \\
\text { media dengan } \\
\text { karakteristik } \\
\text { siswa }\end{array}$ & 4 & 1 & 4 & Baik \\
$\mathbf{2}$ & $\begin{array}{l}\text { Kemudahan } \\
\text { dalam } \\
\text { penggunaan }\end{array}$ & 11 & 3 & 3,67 & Baik
\end{tabular}

\begin{tabular}{|c|c|c|c|c|c|}
\hline \multicolumn{6}{|c|}{ media } \\
\hline 3 & Keterbacaan & 15 & 4 & 3,75 & Baik \\
\hline 4 & Bentuk & 30 & 7 & 4,3 & $\begin{array}{c}\text { Sangat } \\
\text { Baik }\end{array}$ \\
\hline 5 & Warna & 8 & 2 & 4 & Baik \\
\hline 6 & Gambar & 18 & 4 & 4,5 & $\begin{array}{c}\text { Sangat } \\
\text { Baik }\end{array}$ \\
\hline 7 & Video & 16 & 4 & 4 & Baik \\
\hline 8 & Keterpaduan & 7 & 2 & 3,5 & Baik \\
\hline 9 & Keamanan & 5 & 1 & 5 & $\begin{array}{c}\text { Sangat } \\
\text { Baik }\end{array}$ \\
\hline 10 & $\begin{array}{l}\text { Daya tahan } \\
\text { (umur) media } \\
\text { Kemampuan } \\
\text { media dalam } \\
\text { mengembang }\end{array}$ & 5 & 1 & 5 & $\begin{array}{c}\text { Sangat } \\
\text { Baik }\end{array}$ \\
\hline 11 & $\begin{array}{l}\text { kan suasana } \\
\text { belajar yang } \\
\text { menyenangka } \\
\text { n }\end{array}$ & 4 & 1 & 4 & Baik \\
\hline \multicolumn{2}{|c|}{$\begin{array}{l}\Sigma \text { Skor } \\
\text { Keseluruhan }\end{array}$} & & \multicolumn{2}{|r|}{123} & \\
\hline \multicolumn{2}{|c|}{$\Sigma$ Butir } & & \multicolumn{2}{|r|}{30} & \\
\hline \multirow{2}{*}{\multicolumn{2}{|c|}{ Keseluruhan }} & & \multicolumn{2}{|r|}{4,1} & \\
\hline & gori & & \multicolumn{2}{|c|}{ Baik/Layak } & \\
\hline
\end{tabular}

Berdasarkan hasil penilaian dari tahap validasi pertama maka dapat disimpulkan bahwa media puzzle puzila memiliki skor total 123 dengan rata-rata 4,1 yang artinya media ini memiliki tingkat kelayakan dalam kategori "Baik". Dalam validasi I tersebut, ahli media memberikan beberapa saran sebagai dasar perbaikan media. Setelah peneliti melakukan revisi media Puzzle Puzila berdasarkan saran dari ahli media, maka langkah selanjutnya adalah peneliti melakukan validasi lanjutan. Validasi ke II dilakukan pada tanggal 2 Juni 2021 pukul 11.00 yang bertempat di Kantor Jurusan Teknologi Pendidikan. Berikut merupakan kesimpulan dari hasil validasi yang sudah peneliti lakukan.

Tabel 5. Hasil Validasi Ahli Media Tahap II

\begin{tabular}{llcccc}
\hline No & \multicolumn{1}{c}{ Aspek } & $\begin{array}{c}\boldsymbol{\Sigma} \\
\text { Skor }\end{array}$ & $\begin{array}{c}\boldsymbol{\Sigma} \\
\text { Butir }\end{array}$ & $\overline{\mathbf{X}}$ & Kategori \\
\hline $\mathbf{1}$ & $\begin{array}{l}\text { Kesesuaian } \\
\text { media dengan } \\
\text { karakteristik } \\
\text { siswa }\end{array}$ & 4 & 1 & 4 & Baik \\
$\mathbf{2}$ & $\begin{array}{l}\text { Kemudahan } \\
\text { dalam } \\
\text { penggunaan } \\
\text { media }\end{array}$ & 12 & 3 & 4 & Baik \\
$\mathbf{3}$ & $\begin{array}{l}\text { Keterbacaan } \\
\mathbf{4}\end{array}$ & 16 & 4 & 4 & $\begin{array}{c}\text { Baik } \\
\text { Bentuk }\end{array}$ \\
$\mathbf{5}$ & Warna & 8 & 7 & 4,4 & $\begin{array}{c}\text { Sangat } \\
\text { Baik }\end{array}$ \\
& & 2 & 4 & Baik
\end{tabular}




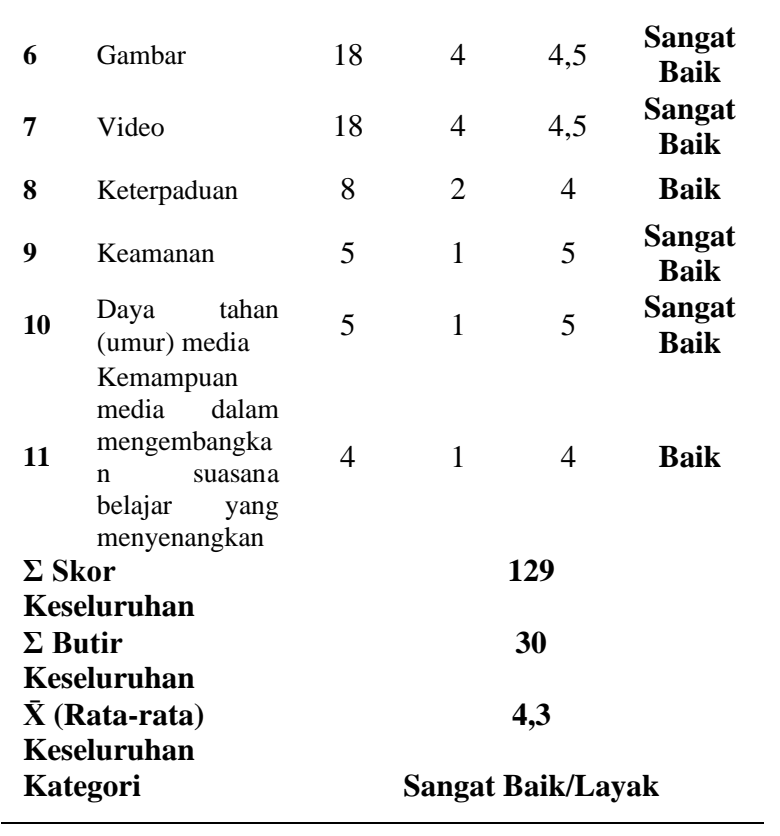

Berdasarkan hasil dari validasi tersebut, media Puzzle Puzila setelah dilakukan revisi mendapatkan skor total keseluruhan sebesar 129 dengan rata-rata 4,3. Hal tersebut menunjukkan bahwa media ini masuk dalam kategori kelayakan "Sangat Baik". Namun, ahli media masih memberikan saran perbaikan. Saran yang diberikan oleh ahli media adalah membuat video menjadi full screen dan untuk menampilkannya tidak perlu mendeteksi marker terus-menerus. Oleh karena itu peneliti memperbaiki sistem AR yang dibuat sesuai dengan saran ahli media. Setelah peneliti melakukan perbaikan atas saran yang diberikan oleh ahli media, peneliti melakukan konsultasi via Whatsapp mengenai hasil revisi tersebut tanpa tanpa harus mengisi ulang instrumen penilaian. Oleh karena itu, kesimpulan dari penilaian media dari Puzzle Puzila adalah "Layak untuk diuji cobakan tanpa revisi". Validasi media dilakukan dengan melakukan penilaian selama 2 Tahap. Berikut merupakan grafik dari hasil penilaian ahli media yang dilakukan dengan 2 Tahap.

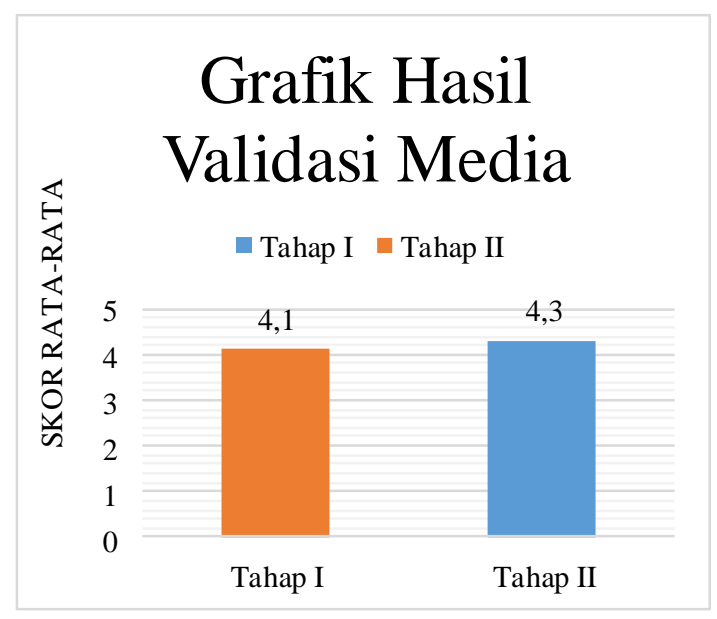

Gambar 1. Grafik Hasil Validasi Media

\section{3) Validasi oleh Guru}

Validasi media Puzzle Puzila oleh guru dilakukan bertujuan untuk mengetahui kelayakan media berdasarkan pandangan dari praktisi pembelajaran. Dalam penelitian ini penilaian dilakukan oleh wali kelas 4 SD IT Bina Insan Kamil yaitu Arif Herlambang Utama. S.Si, S.Pd. Tahap validasi kepada praktisi pembelajaran tersebut dilakukan peneliti pada tanggal 4 Juni 2021 pada pukul 09.00 di Ruang Kelas 4 SD IT Bina Insan Kamil dengan mengikuti protokol kesehatan. Berikut merupakan hasil dari penilaian yang sudah dilakukan oleh guru:

Tabel 6. Hasil Validasi Guru

\begin{tabular}{|c|c|c|c|c|c|}
\hline No & Aspek & $\begin{array}{c}\Sigma \\
\text { Skor }\end{array}$ & $\begin{array}{c}\Sigma \\
\text { Butir }\end{array}$ & $\overline{\mathbf{X}}$ & Kategori \\
\hline 1 & $\begin{array}{ll}\text { Kesesuaian } & \text { materi } \\
\text { dengan } & \text { tujuan } \\
\text { pembelajaran }\end{array}$ & 10 & 2 & 5 & $\begin{array}{l}\text { Sangat } \\
\text { Baik }\end{array}$ \\
\hline 2 & Keterbacaan & 8 & 2 & 4 & Baik \\
\hline 3 & Warna & 8 & 2 & 4 & Baik \\
\hline 4 & $\begin{array}{l}\text { Dukungan } \\
\text { terhadap materi }\end{array}$ & 8 & 2 & 4 & Baik \\
\hline 5 & $\begin{array}{l}\text { Kemampuan } \\
\text { media dalam } \\
\text { mengembangkan } \\
\text { suasana belajar } \\
\text { yang } \\
\text { menyenangkan }\end{array}$ & 5 & 1 & 5 & $\begin{array}{l}\text { Sangat } \\
\text { Baik }\end{array}$ \\
\hline 6 & $\begin{array}{l}\text { Sesuai dengan } \\
\text { taraf } \\
\text { siswa }\end{array}$ & 8 & 2 & 4 & Baik \\
\hline 7 & $\begin{array}{l}\text { Kesesuaian dengan } \\
\text { lingkungan belajar }\end{array}$ & 4 & 1 & 4 & Baik \\
\hline 8 & $\begin{array}{l}\text { Kemudahan dan } \\
\text { keterlaksanaan } \\
\text { pemanfaatan } \\
\text { media }\end{array}$ & 12 & 3 & 4 & Baik \\
\hline
\end{tabular}




$\begin{array}{lc}\Sigma \text { Skor Keseluruhan } & \mathbf{6 3} \\ \Sigma \text { Butir Keseluruhan } & 15 \\ \overline{\mathbf{X}} \text { (Rata-rata) } & \mathbf{4 , 2} \\ \text { Keseluruhan } & \text { Baik/Layak } \\ \text { Kategori } & \end{array}$

Berdasarkan validasi yang dilakukan oleh guru tersebut, media Puzzle Puzila memperoleh jumlah skor sebanyak 63 dengan rata-rata skor keseluruhan yaitu $\mathbf{4 , 2}$ sehingga media ini masuk dalam kategori "Baik".

\section{4) Uji Coba Terbatas}

Uji coba terbatas dilakukan dengan subjek skala kecil yaitu dengan jumlah sampel 12 orang siswa dari total populasi 25 orang kelas 4 SD IT Bina Insan Kamil. Dasar pengambilan sampel karena adanya pandemik COVID-19 dan sekolah hanya mengijinkan uji coba pada 1 rombel saja. Serta hanya diuji cobakan sebanyak 1 kali. Media puzzle puzila di uji cobakan secara langsung pada 12 orang siswa pada tanggal 7 Juni 2021 pukul 09.00 dengan menerapkan protokol kesehatan di Mushola SD IT Bina Insan Kamil. Pada saat uji coba peneliti memberikan waktu bermain kepada siswa dan diberikan angket respon sebagai instrumen pengambilan data. Berikut merupakan hasil dari angket respon yang sudah dinilai siswa pada tahap uji coba:

Tabel 7. Hasil Uji Coba Siswa

\begin{tabular}{cccccc}
\hline No & \multicolumn{1}{c}{ Aspek } & $\begin{array}{c}\boldsymbol{\Sigma} \\
\text { Skor }\end{array}$ & $\begin{array}{c}\boldsymbol{\Sigma} \\
\text { Butir }\end{array}$ & $\overline{\mathbf{X}}$ & Kategori \\
\hline $\mathbf{1}$ & $\begin{array}{l}\text { Kemudahan } \\
\text { penggunaan }\end{array}$ & 48 & 48 & 1 & Baik \\
$\mathbf{2}$ & $\begin{array}{l}\text { Huruf dan } \\
\text { Tulisan }\end{array}$ & 24 & 24 & 1 & Baik \\
$\mathbf{3}$ & Warna & 12 & 12 & 1 & Baik \\
$\mathbf{4} \quad$ Gambar & 12 & 12 & 1 & Baik \\
$\mathbf{5} \quad \begin{array}{l}\text { Kemenarik } \\
\text { an media }\end{array}$ & 12 & 12 & 1 & Baik \\
$\mathbf{6} \quad \begin{array}{l}\text { Keaktifan } \\
\text { siswa }\end{array}$ & 12 & 12 & 1 & Baik \\
$\mathbf{\Sigma}$ Skor & & & $\mathbf{1 2 0}$ & \\
$\begin{array}{l}\text { Keseluruhan } \\
\mathbf{\Sigma} \text { Butir } \\
\text { Keseluruhan } \\
\overline{\mathbf{X}} \text { (Rata-rata) } \\
\text { Keseluruhan } \\
\text { Kategori }\end{array}$ & & & $\mathbf{1 2 0}$ & \\
\hline
\end{tabular}

Berdasarkan hasil akhir dari penilaian oleh siswa saat dilakukan uji coba, maka media Puzzle Puzila memperoleh skor sebesar
120 dengan rata-rata skor 1 dan masuk dalam kategori "Baik". Pada saat mengisi angket respon siswa hanya memberikan tanggapan bahwa media Puzzle Puzila sangat menarik dan menyenangkan untuk dimainkan. Berikut merupakan hasil akhir produk Puzzle Puzila berbasis Augmented Reality:

Tahap disseminate (penyebarluasan) dilakukan dengan melakukan pengemasan akhir dengan identitas lengkap dan diberikan kepada SD IT Bina Insan Kamil sebagai subjek penelitian. Selain itu untuk memperkuat kepemilikan dari media ini peneliti melakukan pendaftaran HKI yang dilakukan di LPPM UNY dan sedang dalam proses pengajuan hak cipta.

Produk puzzle APE Puzzle Puzila berbasis Augmented Reality telah berhasil dikembangkan oleh peneliti. Media ini sangatlah fleksibel penggunaannya karena dapat digunakan dalam kondisi pandemik saat ini yang menerapkan pembelajaran secara daring yaitu dengan menggunakan aplikasi Augmented Reality saja. Marker dalam puzzle dapat diganti dengan gambar secara digital kemudian di scan melalui aplikasi. Marker tersebut telah peneliti sediakan dalam link unduh aplikasi Augmented Reality.

\section{Kelayakan Media}

Kelayakan dari media Puzzle Puzila dapat diketahui setelah peneliti melakukan penilaian kepada ahli materi, ahli media, guru sebagai paktisi pembelajaran hingga dilakukan uji coba pada siswa. Dapat disimpulkan bahwa berdasarkan penilaian tersebut media Puzzle Puzila layak untuk dapat digunakan dalam pembelajaran pendidikan kewarganegaraan di kelas $4 \mathrm{SD}$ IT Bina Insan Kamil. Berikut merupakan penjelasan dari masing-masing penilaian:

\section{A. Ahli Materi}

Validasi materi yang dilakukan oleh ahli materi bertujuan untuk mengetahui kelayakan dari materi yang dikembangkan dalam media Puzzle Puzila. Instrumen diberikan dengan total aspek 5 butir yang terdiri dari 9 butir pertanyaan dengan 5 skala alternatif jawaban mulai dari Sangat Baik, Baik, Cukup, Kurang dan Sangat Kurang. Berdasarkan hasil dari validasi materi tersebut, dapat disimpulkan bahwa media puzzle puzila memiliki skor total 37 dengan rata-rata 4,1 yang artinya media ini memiliki tingkat kelayakan dalam kategori "Baik". 
Ahli materi memberikan komentar bahwa Indikator 3.1.1 yang berbunyi "Menjelaskan makna sila pertama Pancasila" belum nampak pada soal di quiz aplikasi. Pada validasi tersebut, media puzila memperoleh kesimpulan "Layak untuk diuji cobakan dengan revisi". Oleh karena itu peneliti melakukan perbaikan bagian soal agar sesuai dengan indikator capaian. Setelah dilakukan perbaikan penilaian memperoleh kesimpulan "Layak untuk diuji cobakan tanpa revisi".

\section{B. Ahli Media}

Validasi media yang dilakukan oleh ahli media bertujuan untuk mengetahui kelayakan dari bentuk media Puzzle Puzila berbasis Augmented Reality yang sudah dikembangkan oleh peneliti. Instrumen diberikan dengan total aspek sebanyak 11 aspek yang terdiri atas 30 butir pertanyaan dengan 5 skala alternatif jawaban yaitu Sangat Baik, Baik, Cukup, Kurang dan Sangat Kurang. Validasi oleh ahli media ini dilakukan sebanyak 2 tahap. Berdasarkan hasil penilaian dari tahap validasi pertama dapat disimpulkan bahwa media puzzle puzila memiliki skor total 123 dengan ratarata 4,1 yang artinya media ini memiliki tingkat kelayakan dalam kategori "Baik". Oleh karena itu, kesimpulan dari penilaian ini adalah "Layak untuk diuji cobakan dengan revisi". Dalam validasi I tersebut, ahli media memberikan beberapa saran sebagai dasar perbaikan media. Berikut merupakan daftar revisi dari media puzzle puzila:

1) Merubah jarak antar marker agak dijauhkan agar tidak terdeteksi 2 atau lebih object yang muncul. Desain bisa dibuat lebih menarik untuk siswa SD Kelas 4.

2) Mengubah ukuran box. Alternatif model box lebih dibuat minimalis dan mudah dibawa.

3) Mengubah audio video dalam aplikasi menjadi lebih jernih.

4) Desain panduan dibuat terpisah dan bisa dalam bentuk buku.

5) Merubah desain tombol materi di tiap sila dibuat beda agar jelas kapan terbaca markernya.

6) Menambahkan panduan di aplikasi penggunaan harus dalam posisi landscape.
7) Merubah desain Quiz dengan di awal ditambahpetunjuk pengerjaan serta di akhir ketika skor muncul beri kalimat apresiasi dan jawaban yang benar.

Setelah peneliti melakukan revisi media Puzzle Puzila berdasarkan saran dari ahli media, maka langkah selanjutnya adalah peneliti melakukan validasi lanjutan. Berdasarkan hasil dari validasi tersebut, media Puzzle Puzila setelah dilakukan revisi mendapatkan skor total keseluruhan sebesar 129 dengan rata-rata 4,3. Hal tersebut menunjukkan bahwa media ini masuk dalam kategori kelayakan "Sangat Baik". Namun, ahli media masih memberikan saran perbaikan sehingga kesimpulan dari penilaian ke II ini adalah "Layak diujicobakan dengan revisi”". Saran yang diberikan oleh ahli media adalah membuat video menjadi full screen dan untuk menampilkannya tidak perlu mendeteksi marker terus-menerus. Oleh karena itu peneliti memperbaiki sistem AR yang dibuat sesuai dengan saran ahli media. Setelah peneliti melakukan perbaikan atas saran yang diberikan oleh ahli media, peneliti melakukan konsultasi via Whatsapp mengenai hasil revisi tersebut tanpa tanpa harus mengisi ulang instrumen penilaian. Oleh karena itu, kesimpulan dari penilaian media dari Puzzle Puzila adalah "Layak untuk diuji cobakan tanpa revisi”.

\section{Guru}

Validasi oleh guru dilakukan untuk mengetahui kelayakan media berdasarkan penilaian dari praktisi pembelajaran. Instrumen diberikan dengan total aspek sebanyak 8 aspek yang terdiri atas 15 butir pertanyaan dengan 5 skala alternatif jawaban yaitu Sangat Baik, Baik, Cukup, Kurang dan Sangat Kurang. Berdasarkan validasi yang dilakukan oleh guru tersebut, media Puzzle Puzila memperoleh jumlah skor sebanyak 63 dengan rata-rata skor keseluruhan yaitu 4,2 sehingga media ini masuk dalam kategori "Baik" dan memperoleh kesimpulan "Layak diuji cobakan tanpa revisi".

\section{Uji coba Siswa}

Tahap uji coba dilakukan bertujuan untuk mengetahui respon dari siswa sebagai subjek pembelajar. Uji coba media Puzzle Puzila dilakukan kepada 12 orang siswa yang termasuk dalam 1 rombongan belajar karena adanya COVID-19. Sekolah pun hanya mengijinkan untuk diuji cobakan pada 1 
rombel dengan jumlah percobaan sebanyak 1 kali. Intrumen uji coba dengan total 6 aspek penilaian terdiri atas 10 butir pertanyaan dengan alternatif jawaban sebanyak 2 yaitu $\mathrm{Ya}$ dan Tidak. Berdasarkan hasil akhir dari penilaian oleh siswa saat dilakukan uji coba, maka media Puzzle Puzila memperoleh skor sebesar 120 dengan rata-rata skor 1 dan masuk dalam kategori "Baik". Pada saat mengisi angket respon siswa hanya memberikan tanggapan bahwa media Puzzle Puzila sangat menarik dan menyenangkan untuk dimainkan. Oleh karena itu, dapat disimpulkan dalam tahap uji coba ini bahwa media Puzzle Puzila "Layak digunakan untuk pembelajaran tanpa revisi".

Produk puzzle APE Puzzle Puzila berbasis Augmented Reality telah berhasil diketahui kelayakannya yaitu bahwa APE ini layak untuk digunakan dalam proses pembelajaran di kelas. Berdasarkan uji kelayakan yang sudah dilakukan penguji pada siswa kelas 4 SD IT Bina Insan Kamil memberikan kesimpulan bahwa siswa sangat menyukai dan tertarik belajar sambil bermain dengan media ini. Beberapa tanggapan dari mereka menyatakan bahwa media ini menyenangkan untuk dipelajari. Namun mereka juga memberikan saran untuk pengembangan kedepannya untuk lebih ditambahkan lagi materinya bukan hanya pancasila serta menambahkan gambar-gambar lain yang lebih menarik. Beberapa siswa mengungkapkan bahwa puzzle sangat mudah dan menyenangkan untuk dimainkan. Siswa berharap potongan puzzle dapat dipersulit lagi karena lebih menantang.

\section{PENUTUP}

Berdasarkan data yang telah dipaparkan sebelumnya di hasil penelitian dan pembahasan, maka dapat diperoleh kesimpulan dari penelitian ini adalah sebagai berikut.

1. Pengembangan Alat Permainan Edukatif puzzle Puzila berbasis augmented reality sebagai penanaman nilai-nilai pancasila di kelas 4 SD IT Bina Insan Kamil telah menempuh 4 langkah dari model 4-D dari Thiagarajan yaitu tahap Define (Pendefinisian), Design (Perancangan), Develop (Pengembangan), dan Disseminate (Penyebarluasan). Tahap Define (Pendefinisian) terdiri atas tahap analisis awal, analisis siswa, analisis tugas, analisis konsep dan spesifikasi tujuan pembelajaran. Tahap Design (Perancangan) terdiri atas penyusunan instrumen penilaian kelayakan, pemilihan media, pemilihan format, dan rancangan awal media. Tahap Develop (Pengembangan) dilalui dengan tahap validasi ahli materi, ahli media, guru dan uji coba kepada siswa. Tahap Disseminate (Penyebarluasan) dilalui dengan tahap pengemasan dan pemberian identitas pengembang serta penyebarluasan dengan memberikan media kepada SD IT Bina Insan Kamil.

2. Produk Alat Permainan Edukatif puzzle Puzila berbasis augmented reality sebagai penanaman nilai-nilai pancasila di kelas 4 SD IT Bina Insan Kamil berdasarkan validasi dari ahli materi dan ahli media dinyatakan layak untuk digunakan dalam proses pembelajaran. Hal tersebut terbukti dari hasil validasi ahli materi yang memperoleh skor rata-rata sebesar $\mathbf{4 , 1}$ (Layak), validasi ahli media dengan perolehan skor rata-rata sebesar $\mathbf{4 , 3}$ (Layak), validasi guru dengan perolehan skor rata-rata sebesar 4,2 (Layak), dan tahap uji coba siswa diperoleh skor ratarata dari data respon sebesar 1 (Layak).

\section{UCAPAN TERIMA KASIH}

Penulis menyadari bahwa dalam penulisan Artikel ini tidak dapat terlaksana tanpa bantuan, dukungan serta bimbingan dari berbagai pihak yang ikut berkontribusi dalam penelitian ini. Oleh karena itu, perkenankanlah penulis memberikan ucapan terima kasih yang sedalam-dalamnya kepada :

1. Bapak Fathurrohman, M.Pd., selaku validator ahli materi yang telah memberikan masukan dalam penelitian ini.

2. Bapak Ariyawan Agung Nugroho, S.T.,M.Pd., selaku validator ahli media yang telah memberikan masukan dalam penelitian ini.

3. Bapak Athar selaku Kepala SD IT Bina Insan Kamil yang telah memberikan ijin dalam pelaksanaan penelitian ini.

4. Bapak Arif Herlambang, S.Si,. S.Pd., selaku Wali Kelas 4 SD IT Bina Insan Kamil beserta para guru dan staf yang telah membantu melancarkan dalam proses pengambilan data dalam penelitian ini. 
5. Serta semua pihak yang secara langsung maupun tidak langsung telah membantu dalam penelitian ini.

\section{DAFTAR PUSTAKA}

Ariyanti., dkk. (2015). Efektivitas Alat Permainan Edukatif (APE) Berbasis Media dalam Meningkatkan Kemampuan Berhitung pada Anak Kelas 2 di SDN 2 Wonotirto Bulu Temanggung. Jurnal Psikologi Tabularasa, 10(1) : 58-69.

Azuma, R. T. (1997). A Survey Of Augmented Reality. Presence: Teleoperators and Virtual Environments, 6 (4) : 355-385.

Budiman, H. (2017). Peran Teknologi dan Komunikasi Dalam Pendidikan. Al-Tadzkiyyah: Jurnal Pendidikan Islam, 8 (1): 32.

Buchori, A, dkk. (2017). Effectiveness of Direct Instruction Learning Strategy Assisted by Mobile Augmented Reality and Achievement Motivation on Students Cognitive Learning Results. Asian Social Science, 13 (9) : 137-144.

Burhaein, E. (2017). Aktivitas Fisik Olahraga untuk Pertumbuhan dan Perkembangan Siswa SD. Indonesian Journal of Primary Education, 1 (1) : 51-58.

JPPN. (2018). 24 dari 100 Orang Indonesia Tidak Hafal Pancasila. Diakses dari

https://www.jpnn.com/news/24dari-100-orang-indonesia-tidakhafal-pancasila pada tanggal 18 Maret 2021.

Mulyatiningsih, E. (2012). Metode Penelitian Terapan Bidang Pendidikan. Bandung: Alfabeta.

Saputro, R., dkk. (2015). Pengembangan Media Pembelajaran Mengenal Organ Pencernaan Manusia Menggunakan Teknologi
Augmented Reality. Jurnal

Buana Informatika, 6(2).153-162

Soetjiningsih. (2002). Tumbuh Kembang Anak. Cetakan II. Jakarta : EGC.

Sugiyono. (2016). Metode Penelitian Kuantitaif, Kualitatif, dan $R \& D$. Bandung. Alfabeta.

Suharso, A. (2011). Model Pembelajaran Interaktif Bangun Ruang 3D Berbasis Augmented Reality. Majalah Ilmiah SOLUSI, 11(24). 1-11

Suyadi. (2009). Permainan Edukatif yang Mencerdaskan. Yogyakarta: Power Books (IHDINA).

Susilana., dkk. (2007). Media Pembelajaran. Bandung : CV. Wacana Prima.

Thiagarajan, S. (1974). Instructional Developmentfor Training Teachers of Exceptional Children : A Surcebook. Center for Innovationin Teaching the Handicapped. Tersedia di Eric

Widiatmaka, P. (2016). Kendala Pendidikan Kewarganegaraan Dalam Membangun Karakter Peserta Didik di Dalam Proses Pembelajaran. Jurnal Civics, 13 (2): 197.

Widoyoko, E.P. (2009). Evaluasi Program Pembelajaran (Panduan Praktis bagi Pendidik dan Calon Pendidik). Yogyakarta: Pustaka Pelajar.

Yudha. (2007). Cara pintar mendongeng. Bandung : PT Mizan Bunaya Kreativa

Yusliawan, K., dkk. (2014). Kelayakan Teoretis Media Pembelajaran Puzzle Digital Pada Materi Struktur DNA untuk Kelas XII. Bioedu : Berkala Ilmiah Pendidikan Biologi, 3 (1) : 329332 